UDC 636.

(i)

N. Basiurkina, Doctor of Science, Professor, E-mail: nbas@ gmail.com ORCID.org/0000-0001-9342-8863, ResearcherID: P-7931-2015

B. Iegorov, Doctor of Science, Professor, E-mail: bogdanegoroff58@ gmail.com ORCID 0000-0001-7526-0315, ResearcherID: Q-1365-2015, Scopus Author ID: 56578802600

A. Makarynska, PhD. Sc., Ass. Professor, E-mail: allavm2015@gmail.com ORCID: 0000-0003-1879-8455, Researcher ID: C-5217-2016, Scopus ID: 57192819060

Department of Technology of Mixed Feeds and Biofuel Odessa National Academy of Food Technologies, 112, Kanatna Str., 65039, Odessa, Ukraine, +38487124113

\title{
ASSESSMENT OF THE NEEDS AND ECONOMIC EFFICIENCY OF PREMIXES, PROTEIN AND VITAMIN SUPPLEMENTS AND MIXED FODDER'S
}

\begin{abstract}
The article presents statistics on the number of pigs and poultry in Ukraine and Odessa region for 1990-2019 and the results of the calculation of needs for premixes and protein-vitamin supplements (PVS) in Ukraine, and in particular, in Odessa region, the average increase and volumes of compound feed consumption. The main purpose of the calculation is to determine the production potential of premixes and compound feeds in Ukraine and in the region, the cost of compound feeds in poultry farming using different types of premixes and PVS.

According to the Main Department of Statistics in Odesa Oblast, the number of pigs has decreased over the past five years, and the number of poultry has increased by $7.3 \%$.

The calculation of the need for premixes and PVS is determined by the volume of feed production, the need for which depends on the number of livestock and poultry, data on their average growth and consumption of feed.

The method of calculating the number of pigs and poultry (forecast) depending on the needs of the population in livestock food, as well as the results of the forecast of the number of pigs and chickens in Ukraine and Odessa region for 2020-2023, which amounted to 5702, 0 and 173.0 thousand goals, 224.8 and 3.3 million goals, respectively.

The calculations taking into account the export-import potential of raw materials showed that in the Odessa region there is a shortage of capacity, namely: $P$ mf forecast $=104819.6$ thousand tons. $>0, P \mathrm{mf}$ forecast $\geq M$ year, ie $104819.6>9000.0$ thousand tons, so in the Odessa region should provide a feed mill with a capacity of 15 thousand tons per shift in two shifts is appropriate and reasonable. The potential of production and sale of compound feeds in the Odessa region, which is up to 8500 thousand tons of feed, 85 thousand tons of premixes and 2430 thousand tons of PVS, calculated the main producers and consumers of feed products.

The estimated economic efficiency of the use of feed enriched with complex premixes, as a result of which it is possible to reduce the cost of obtaining 10 eggs to 280 million UAH. per year, and in the fattening of suckling piglets - zeko-nomity in the production of pork up to 3.15 million UAH.
\end{abstract}

Key words: compound feed for turkeys, physical properties, chemical composition, protein feed additive, soybean meal, nutritional indicators.

\section{Introduction}

The calculation of the need for premixes and PVS in Ukraine and in particular in Odessa region is determined by the volume of feed production, the need for which depends on the number of livestock and poultry, data on their average growth and feed consumption.

The purpose of the calculation is to determine the production potential of premixes and compound feeds in Ukraine and in the region, the cost of compound feeds in poultry farming using different types of premixes and PVS.

According to the State Statistics Service of Ukraine, the number of farm animals and poultry (Table 1) has a tendency to slow. Over the past five years, the decline in the number of pigs has stabilized and the number of birds has increased by $7.3 \%$.

The number of pigs and poultry in the Odessa region according to the Main Department of Statistics in the Odessa region is presented in table. 1 .

From the data in Table 1 it follows that the situation in Ukraine and in the Odessa region differs, which should be taken into account when forecasting the share of feed in packaged form. But, given that the Odessa region is not a leader in breeding farm animals, we will rely on the average in Ukraine in 2019 and trends in the number of pigs and poultry.

The analysis of livestock, namely pigs and poultry, by farm category is important to clarify the following issues:

- what is the potential of production and sale of premixes and compound feeds for enterprise capacity planning;

- in what proportion to produce loose and prepackaged products;

- in which containers and packaging the finished feed products will be sold to large and small enterprises.

Taking into account agricultural enterprises, $10 \%$ will be produced in packaged form.

An important role in calculating the cost of feed products is played by the location of the enterprise and modern logistics infrastructure for the delivery of drugs BAR and GP to other regions. According to the Main Department of Statistics in Odessa region, the 
Table 1 - Number of pigs and poultry in Ukraine for 2000-2020 [1-3]

\begin{tabular}{|c|c|c|c|c|c|c|}
\hline \multirow[b]{2}{*}{ Years } & \multicolumn{3}{|c|}{ Pig, thousand heads } & \multicolumn{3}{|c|}{ Poultry, million heads } \\
\hline & In general & $\begin{array}{c}\text { Agricultural } \\
\text { enterprises }\end{array}$ & Households & In general & $\begin{array}{c}\text { Agricultural } \\
\text { enterprises }\end{array}$ & Households \\
\hline 2000 & 7652 & 2414 & 5238 & 123,7 & 25,3 & 98,4 \\
\hline 2005 & 7053 & 2602 & 4451 & 162,0 & 66,6 & 95,4 \\
\hline 2015 & 7079 & 3704 & 3375 & 204,0 & 112,0 & 92,0 \\
\hline 2016 & 6669 & 3566 & 3103 & 201,7 & 109,8 & 91,9 \\
\hline 2017 & 6110 & 3304 & 2806 & 204,8 & 112,5 & 92,3 \\
\hline 2018 & 6025 & 3396 & 2630 & 211,7 & 118,8 & 92,9 \\
\hline 2019 & 5702 & 3366 & 2336 & 219,4 & 126,8 & 92,6 \\
\hline $\begin{array}{c}\text { Structure in } \\
2019, \%\end{array}$ & 100,0 & 59,0 & 41,0 & 100,0 & 57,8 & 42,2 \\
\hline \multicolumn{7}{|c|}{ The number of pigs and poultry in the Odessa region } \\
\hline 2019 & 173,0 & 64,1 & 108,9 & 3173,5 & 135,9 & 3037,6 \\
\hline Structure, $\%$ & 100,0 & 37,1 & 62,9 & 100,0 & 4,3 & 95,7 \\
\hline $\begin{array}{c}2020 \\
\text { on March } 1 \\
\end{array}$ & 145,9 & 54,1 & 91,8 & 2388,3 & 102,3 & 2286,0 \\
\hline
\end{tabular}

number of farm animals by cities of regional importance and districts of the region are presented in table. 2. This statistical information is given for enterprises that keep from 200 heads of pigs and / or from 5000 heads of poultry of all species.

From the logistical point of view for the further export of compound feed products to other countries and regions the lowest transport costs will be for the enterprise located in Odessa, Chernomorsk, Ovidiopol district or Belgorod-Dniester district. In addition, there are large grain-saving and grain-processing enterprises, which are logical to expand activities (diversification) and the organization of feed production [4].

\section{Results and its discussion}

The number of farm animals is an indicator that varies in the direction of increase, we take this into account and calculate its value in the future [4]. Yes, the number of livestock per run is calculated by the formula:

$\mathrm{K}$ livestock forecast $=\mathrm{K}$ livestock basic $-\mathrm{K}$ livestock, thousand goals,

where $\mathrm{K}_{\text {base }}$ - average number of livestock (pigs / chickens) in the current year, thousand heads;

$\mathrm{K}_{\text {livestock }}$ - average number of livestock (pigs / chickens) in the future, in this example it is in 4 years - in 2022), thousand heads;

$\mathrm{Kn}$ - adjustment factor that takes into account the increase / decrease in the number of livestock (pigs / chickens), which is calculated by the formula:

$$
\mathrm{Kn}=\mathrm{Kpc} \times \mathrm{t} \text {, }
$$

where Kpc - index of growth / decrease in the number of livestock (pigs / chickens) (for pigs is equal to 1.00 , for chickens $1.02 \ldots 1.04)$; $\mathrm{t}$ - the period of time associated with the duration of any project is 4 years.

Number of chickens $\left(\mathrm{K}_{\text {chickens basic }}\right)$ according to the structure of poultry in Ukraine, as a share of the number of poultry $(91 \%)$ :

$\mathrm{K}_{\text {chickens basic }}=\mathrm{K}_{\text {birds basic }} \cdot 0,91$, thousand heads,

where $\mathrm{K}_{\text {basic bird }}$ - the number of poultry in the current year, thousand heads;

We accept the trend of annual growth of poultry until 2023 at $7.3 \%$ and calculate the above indicators in the period up to 2023 (Table 2), ie for the forecast 4 years (from 2020 to 2023).

As a result, the projected weighted average number of pigs in 2023, calculated according to formula (1), is:

\section{in Ukraine:}

$\mathrm{K}_{\text {pig forecast }}=5702.0 \cdot(1.0) 4=5702.0$ thousand goals;

$$
\text { - in the Odessa region: }
$$

$\mathrm{K}_{\text {pig forecast }}=173.0 \cdot(1.0) 4=173.0$ thousand goals.

The basic number of domestic chickens in 2023 is equal to (according to formula 1 ):

$$
\text { in Ukraine: }
$$

$\mathrm{K}_{\text {chickens base }}=219.4 \cdot 0.91=199.7$ million heads;

$$
\text { - in the Odessa region: }
$$

$\mathrm{K}_{\text {chickens basic }}=3173.5 \cdot 0.91=2887.9$ thousand heads.

Then the projected number of chickens in 2023

by formula (3) will be equal to:

$$
\text { in Ukraine: }
$$

$\mathrm{K}_{\text {chickens forecast }}=199.7 \cdot(1.03) 4=224.8$ million heads;

$$
\text { - in the Odessa region: }
$$

$\mathrm{K}_{\text {chickens forecast }}=2887.9 \cdot(1.03) 4=3250.4$ thousand heads.

In order to substantiate the capacity of the feed mill, we calculate the potential for production and sale of 
Table 2 - The number of pigs and poultry by cities of regional importance and districts of Odessa region on March 1, 2020 [1-3]

\begin{tabular}{|c|c|c|c|c|}
\hline \multirow{2}{*}{$\begin{array}{l}\text { Cities of regional significance } \\
\text { and districts }\end{array}$} & \multicolumn{2}{|r|}{ Pig } & \multicolumn{2}{|r|}{ Poultry } \\
\hline & heads & $\begin{array}{l}\text { in\% to the corresponding } \\
\text { date of } 2019\end{array}$ & heads & $\begin{array}{c}\text { in\% to the corresponding } \\
\text { date of } 2019\end{array}$ \\
\hline Odessa region & 70123 & $\begin{array}{r}101,4 \\
\end{array}$ & 95,7 & 62,2 \\
\hline Balta & к & - & - & - \\
\hline Bilyaivka & K & к & - & - \\
\hline \multicolumn{5}{|l|}{ Areas: } \\
\hline Ananievsky & - & - & - & - \\
\hline Artsyz & 15502 & 113,4 & - & - \\
\hline Baltic & К & К & - & - \\
\hline Belgorod-Dniester & 1932 & 143,0 & 14,0 & 50,6 \\
\hline Bilyaivsky & 1702 & 94,9 & 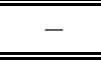 & 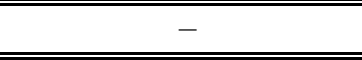 \\
\hline Berezovsky & $\kappa$ & $\kappa$ & - & - \\
\hline Bolgradsky & 16295 & 99,0 & - & - \\
\hline "Velykomykhailivsky & 1268 & $7 \overline{77,8}$ & - & - \\
\hline Ivanovsky & 5142 & 100,9 & - & - \\
\hline Izmail & К & К К & К & К \\
\hline Kiliysky & - & - & 7,9 & 64,3 \\
\hline Kodymsky & - & - & $\begin{array}{l}- \\
\end{array}$ & - \\
\hline Lymansky & - & 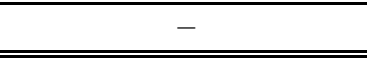 & - & - \\
\hline Podolsky & К & К & - & - \\
\hline Oknyansky & К & K & - & - \\
\hline Lyubashivsky & - & - & - & - \\
\hline Mykolaiv & - & - & - & - \\
\hline Ovidiopolski & К & К & - & - \\
\hline Rozdilnyansky & 807 & 50,7 & - & - \\
\hline Rhine & - & - & - & - \\
\hline Savransky & 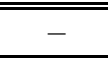 & 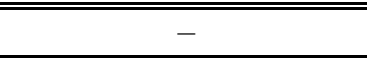 & - & - \\
\hline Saratsky & 325 & 97,6 & 69,4 & 138,1 \\
\hline Tarutynsky & 18516 & 97,1 & К & К К \\
\hline Tatarbunary & - & - & - & - \\
\hline Zakharovsky & К & К & - & - \\
\hline Shiryaevsky & 5350 & 1110,4 & - & - \\
\hline
\end{tabular}

Note: Symbol ( $k$ ) - data are not published in order to ensure compliance with the requirements of the Law of Ukraine "On State Statistics" on the confidentiality of statistical information.

Table 3 - Estimated number of pigs and chickens in Ukraine and in the Odessa region in 2020-2023, thousand heads

\begin{tabular}{|c|c|c|c|c|}
\hline Species & 2020 & 2021 & 2022 & 2023 \\
\hline \multicolumn{5}{|c|}{ Ukraine } \\
\hline $\begin{array}{l}\text { Riggs, } \\
\text { thousand } \\
\text { heads }\end{array}$ & 5702,0 & 5702,0 & 5702,0 & 5702,0 \\
\hline $\begin{array}{l}\text { Chickens, } \\
\text { million } \\
\text { heads }\end{array}$ & 199,7 & 205,7 & 211,9 & 224,8 \\
\hline \multicolumn{5}{|c|}{ Odessa region } \\
\hline $\begin{array}{l}\text { Riggs, } \\
\text { thousand } \\
\text { heads }\end{array}$ & 173,0 & 173,0 & 173,0 & 173,0 \\
\hline
\end{tabular}

\begin{tabular}{|l||l||l||l||l||}
\hline $\begin{array}{l}\text { Chickens, } \\
\text { million } \\
\text { heads }\end{array}$ & 2,9 & 3,0 & 3,1 & 3,3 \\
\hline
\end{tabular}

feed in the Odessa region, and explore the main producers and consumers of feed products. To do this, it is necessary to find the difference between the existing production of feed in the region and the need of farm animals for feed, taking into account the export and import of feed.

Determine the need of farm animals for feed, otherwise the total consumption of feed, according to the formula:

$\mathrm{C}_{\mathrm{mf} \text { forecast }}=\mathrm{C}_{\mathrm{mf} \text { pig forecast }}+\mathrm{C}_{\mathrm{mf} \text { chick forecast }}$, thousand tons, (4) 
where $\mathrm{C}_{\text {mf forecast }}$ - the potential for production of feed for pigs and chickens in the region, thousand tons;

$\mathrm{C}_{\mathrm{mf}}$ pig forecast - the potential for the production of compound feed for pigs in the region, thousand tons;

$\mathrm{C}_{\mathrm{mf} \text { chick forecast }}$ - the potential for production of feed for chickens in the region, thousand tons.

Calculate the total consumption of compound feeds separately for pigs and chickens according to formulas 5 and 6 , respectively:

$$
\mathrm{C}_{\mathrm{mf} \text { pig forecast }}=\mathrm{K}_{\text {pig forecast }} \bullet \mathrm{N}_{\mathrm{mf} \text { pig year }} \text {, thousand tons, }
$$

where $\mathrm{N}_{\text {mf pig year }}$ - average annual consumption of compound feed by one pig, thousand tons;

$\mathrm{C} \mathrm{mf}$ chickens forecast $=\mathrm{K} \mathrm{mf}$ chickens forecast $-\mathrm{N}$ mf chickens year, thousand tons,

where $\mathrm{N}$ mf chickens year - the average annual consumption of feed by one chicken, thousand tons.

The average annual consumption of feed by farm animals is determined by formulas (7) and (8):

$$
\mathrm{H}_{\text {mf pig year }}=\mathrm{H}_{\mathrm{mf} \text { pig day }} \cdot 365 \text {, tonn }
$$

де $\mathrm{H}$ mf pig da - середнє добове споживання комбікорму однією свинею, кг,

$$
\mathrm{H}_{\text {mf chick year }}=\mathrm{H}_{\mathrm{mf} \text { chick day }} \cdot 365 \text {, tonn }
$$

де $\mathrm{H}_{\mathrm{mf}}$ chick day - average daily consumption of compound feed per chicken, $\mathrm{kg}$.

To determine the market demand for the production of feed for pigs, we analyzed the structure of their herd, daily consumption of feed depending on age and purpose based on scientific standards and experience of modern farms and calculated the annual consumption of pig feed. The total annual consumption of compound feeds by all categories of pigs will be equal to the potential for the production of compound feeds for pigs in the Odessa region, taking into account the exportimport potential.

A similar calculation was performed for ku-ray. To calculate the number of chickens in the overall structure of the chicken herd, we assume that the ratio of chickens and roosters averages 1:10 (10\%: 90\%), and are raised in approximately the same number of chickens of meat breeds, egg breeds and broilers, ie one third of the total herd $(33.3 \%)$. The result was the following ratio in the total number of chickens:

- equally hens of meat and egg breeds, 90\% (from $33.3 \%$ ) - 30.0\%;

- equally roosters of meat and egg breeds, $10 \%$ (from $33.3 \%$ ) - 3.3\%;

- broilers - $33.3 \%$.

The average indicators - daily and annual feed norms by species and age of domestic chickens - were calculated as arithmetic mean.

As a result, the projected total annual consumption of feed in the Odessa region in 2023 will be equal to:
$\mathrm{C}_{\mathrm{mf} \text { forecast }}=138.4+104716=104854.4$ thousand tons or 104.9 million tons.

In the Odessa region there are enterprises that are engaged in the production of feed for pigs and chickens, in small volumes there is an import, and a little more and the export of the studied products.

Let's determine the forecast potential of compound feed production for pigs and domestic chickens in the Odessa region $\left(\mathrm{P}_{\mathrm{mf}}\right.$ forecast $)$. As a result, the projected volume - deficit (or surplus) of feed production capacity for pigs and domestic chickens $\left(\mathrm{P}_{\text {mf forecast }}\right)$ is defined as the difference between the forecast consumption $(\mathrm{C}$ mf forecast $)$ and the total volume of feed production $\left(\mathrm{V}_{\mathrm{mf}}\right.$ forecast $)$ with the addition of export $\left(\mathrm{E}_{\mathrm{mf}}\right.$ forecast) and subtraction of imports ( $\mathrm{I}_{\mathrm{mf}}$ forecast $)$ of feed for pigs and chickens according to the formula 9.

$\mathrm{P}_{\text {mf forecast }}=\mathrm{C}_{\mathrm{mf} \text { forecast }}-\mathrm{V}_{\mathrm{mf} \text { forecast }}-\mathrm{E}_{\mathrm{mf} \text { forecast }}+\mathrm{I}_{\mathrm{mf} \text { forecast }}$ , thousand tons, (9)

where $\mathrm{V}$ mf forecast - forecast production of compound feeds for pigs and chickens in the region, thousand tons;

$\mathrm{E}_{\mathrm{mf} \text { forecast }}$ - forecast of export (export) of compound feeds to other regions, thousand tons;

$\mathrm{I}_{\mathrm{mf}}$ forecast - forecast of import (import) of compound feeds from other regions, thousand tons.

Then the production of feed for pigs and chickens in the Odessa region is equal to:

$$
\begin{aligned}
& \mathrm{V}_{\mathrm{mf} \text { forecast }}=\mathrm{V}_{\text {mf pig forecast }}+\mathrm{V}_{\text {mf chicken forecast, }} \text { thousand } \\
& \text { tons, }
\end{aligned}
$$

where $\mathrm{V}$ mf pig forecast - production of compound feeds for pigs in the region, thousand tons;

$\mathrm{V}$ mf chicken forecast - production of compound feeds for domestic chickens in the region, thousand tons.

The volume of compound feed production is an indicator that varies in the direction of increase, we take into account and calculate its value for the future. Thus, the volume of production of feed for pigs and poultry perspective is calculated by the formula:

$$
\mathrm{V}_{\text {mf forecas }}=\mathrm{V}_{\mathrm{mf} \text { base }} \cdot \mathrm{K}_{\mathrm{mf}} \text {, thousand tons, (11) }
$$

where $\mathrm{V}_{\mathrm{mf} \text { base }}$ - volume of feed production in the current, thousand tons. According to statistics in 2019 in the Odessa region, this figure for pigs was 8246 tons, and its increase compared to last year - $43 \%$, for chickens - 1711 tons, and its decrease compared to last year - $8 \%$. Therefore, we take these growth indicators for the future.

$\mathrm{K}$ mf pig - adjustment factor that takes into account the increase / decrease in the number of pigs, which is calculated by the formula:

$$
\mathrm{K}_{\mathrm{mf} \text { pig }}=\mathrm{K}_{\text {mf pig }} \mathrm{t},
$$

where $\mathrm{K}_{\mathrm{mf} \text { pig }}$ - growth / decrease index of the number of pigs (in our case for pigs is equal to 1.43 , for chickens 1.0);

$\mathrm{t}$ - the period of time associated with the duration of the project, ie, the time lag (period of development) of the investment is equal to 4 years. 
Table 4 - Calculation of the total consumption of feed for chickens in the Odessa region in 2023

\begin{tabular}{|c|c|c|c|c|c|c|}
\hline № & The name of the bird & $\begin{array}{l}\text { Onr } 1000 \text { heads } \\
\text { per day, kg, } \\
\mathrm{N}_{\text {mf chickens day }}\end{array}$ & $\begin{array}{c}\text { On } 1000 \\
\text { heads per } \\
\text { year, kg, } \\
\mathrm{N}_{\text {mf chickens year }}\end{array}$ & $\begin{array}{l}\text { Share in the } \\
\text { structure of } \\
\text { the herd, \% }\end{array}$ & \begin{tabular}{||c} 
Number in the \\
structure of the \\
herd ( 3.3 million \\
heads), \\
million heads, \\
$\mathrm{K}_{\text {chickens forecast }}$
\end{tabular} & $\begin{array}{l}\text { Total annual } \\
\text { consumption of } \\
\text { chicken feed, } \\
\text { thousand tons, } \\
\mathrm{S}_{\mathrm{mf} \text { chickens forecast }}\end{array}$ \\
\hline \multirow[t]{9}{*}{1.} & Egg breeds & & & & & \\
\hline & 15 days of life & 21 & 7665 & & & \\
\hline & 30 days of life & 36 & 13140 & & & \\
\hline & 45 days of life & 50 & 18250 & & & \\
\hline & 60 days of life & 60 & 21900 & & & \\
\hline & 90 days of life & 72 & 26280 & & & \\
\hline & 120 days of life & 83 & 30295 & & & \\
\hline & 154 days of life & 95 & 34675 & & & \\
\hline & The average & 60 & 21744 & 30,0 & $\mathbf{0 , 9 9}$ & 21527 \\
\hline \multirow[t]{9}{*}{2.} & Roosters of egg breeds & & & & & \\
\hline & 15 days of life & 23 & 8395 & & & \\
\hline & 30 days of life & 40 & 14600 & & & \\
\hline & 45 days of life & 55 & 20075 & & & \\
\hline & 60 days of life & 66 & 24090 & & & \\
\hline & 90 days of life & 80 & 29200 & & & \\
\hline & 120 days of life & 991 & 33215 & & & \\
\hline & 154 days of life & 105 & 38325 & & & \\
\hline & $\begin{array}{ll}\text { The average } \\
\end{array}$ & 66 & 23986 & $\mathbf{3 , 3}$ & 0,11 & 2638 \\
\hline \multirow[t]{10}{*}{3.} & Meat chickens & & & & & \\
\hline & 15 days of life & 40 & 14600 & & & \\
\hline & 30 days of life & 45 & 16425 & & & \\
\hline & 45 days of life & $\overline{50}$ & 18250 & & & \\
\hline & 60 days of life & 60 & 21900 & & & \\
\hline & 90 days of life & 60 & 21900 & & & \\
\hline & 120 days of life & 63 & 22995 & & & \\
\hline & 150 days of life & 95 & 34675 & & & \\
\hline & 182 days of life & 135 & 49275 & & & \\
\hline & The average & 69 & 25003 & $\mathbf{3 0 , 0}$ & $\mathbf{0 , 9 9}$ & 24753 \\
\hline \multirow[t]{10}{*}{4.} & Meat roosters & & & & & \\
\hline & 15 days of life & 56 & 20440 & & & \\
\hline & 30 days of life & 60 & 21900 & & & \\
\hline & 45 days of life & 68 & 24820 & & & \\
\hline & 60 days of life & 70 & 25550 & & & \\
\hline & 90 days of life & 90 & 32850 & & & \\
\hline & 120 days of life & 100 & 36500 & & & \\
\hline & 150 days of life & 120 & 43800 & & & \\
\hline & 182 days of life & 150 & 54750 & & & \\
\hline & The average & 89 & 32576 & $\mathbf{3 , 3}$ & $\mathbf{0 , 1 1}$ & 3603 \\
\hline \multirow[t]{6}{*}{5.} & Broiler chickens & & & & & \\
\hline & 15 days of life & & & & & \\
\hline & 30 days of life & 135 & 49275 & & & \\
\hline & 49 days of life & 180 & 65700 & & & \\
\hline & The average & 130 & 47450 & 33,4 & 1,1 & 52195 \\
\hline & Total & & & 100,0 & 3,3 & 104716 \\
\hline
\end{tabular}


Table 5 - Calculation of the total consumption of feed for pigs in the Odessa region in 2023

\begin{tabular}{|c|c|c|c|c|c|c|}
\hline № & $\begin{array}{l}\text { Pigs in the herd } \\
\text { structure }\end{array}$ & $\begin{array}{c}\text { Share of } \\
\text { pigs by age } \\
\text { in the struc } \\
\text { ture of the } \\
\text { herd, } \%\end{array}$ & $\begin{array}{l}\text { Number of pigs } \\
\text { by age in the } \\
\text { structure of the } \\
\text { herd ( } 173 \text { thou- } \\
\text { sand heads), thou- } \\
\text { sand heads, } \\
K_{\text {pig forecast }}[2] \\
\end{array}$ & $\begin{array}{c}\text { Average daily } \\
\text { consumption } \\
\text { of compound } \\
\text { feed per pig, } \\
\mathrm{kg}, \mathrm{N}_{\text {mf pig day }} \\
{[5-8]}\end{array}$ & $\begin{array}{l}\text { Average annual } \\
\text { consumption of } \\
\text { compound feed } \\
\text { per pig, tons, } \\
\mathrm{N}_{\text {mf pig year }}\end{array}$ & $\begin{array}{c}\text { Total annual } \\
\text { consumption of } \\
\text { compound feeds } \\
\text { by pigs, thou- } \\
\text { sand tons, } \\
\mathrm{S}_{\text {mf pig forecast }}\end{array}$ \\
\hline \multirow[t]{3}{*}{1.} & Dairy stage & 20,0 & & & & \\
\hline & $\begin{array}{l}\text { Suckling piglets } \\
\text { - 0-2 weeks } \\
\text { - 2-4 weeks }\end{array}$ & $\begin{array}{l}5,0 \\
5,0\end{array}$ & $\begin{array}{l}8,65 \\
8,65\end{array}$ & $\begin{array}{l}0,025 \\
0,250\end{array}$ & $\begin{array}{l}0,009 \\
0,091\end{array}$ & $\begin{array}{l}0,079 \\
0,789\end{array}$ \\
\hline & $\begin{array}{l}\text { Piglets at weaning } \\
-1 \text { month } \\
-2 \text { months }\end{array}$ & $\begin{array}{l}5,0 \\
5,0\end{array}$ & $\begin{array}{l}8,65 \\
8,65\end{array}$ & $\begin{array}{l}0,350 \\
0,850\end{array}$ & $\begin{array}{l}0,128 \\
0,310\end{array}$ & $\begin{array}{l}1,105 \\
2,684\end{array}$ \\
\hline \multirow[t]{2}{*}{2.} & Staging stage & 25,0 & & & & \\
\hline & $\begin{array}{l}\text { Weaned piglets } \\
-3 \text { months } \\
-4 \text { months }\end{array}$ & $\begin{array}{l}12,5 \\
12,5\end{array}$ & $\begin{array}{l}21,63 \\
21,63\end{array}$ & $\begin{array}{l}1,050 \\
1,550\end{array}$ & $\begin{array}{l}0,383 \\
0,566\end{array}$ & $\begin{array}{c}8,290 \\
12,237\end{array}$ \\
\hline \multirow[t]{2}{*}{3.} & The fattening stage & 46,0 & & & & \\
\hline & $\begin{array}{l}\text { Young } \\
-5 \text { months } \\
-6 \text { months } \\
-7 \text { months } \\
-8 \text { months }\end{array}$ & $\begin{array}{l}10,0 \\
11,0 \\
12,0 \\
13,0\end{array}$ & $\begin{array}{l}17,30 \\
19,03 \\
20,76 \\
22,88\end{array}$ & $\begin{array}{l}2,250 \\
2,550 \\
3,200 \\
3,350\end{array}$ & $\begin{array}{l}0,821 \\
0,931 \\
1,168 \\
1,223\end{array}$ & $\begin{array}{l}14,208 \\
17,712 \\
24,248 \\
27,977\end{array}$ \\
\hline \multirow[t]{2}{*}{4.} & Sows & & & & & \\
\hline & $\begin{array}{l}\text { - basic } \\
\text { - checked }\end{array}$ & $\begin{array}{l}5,0 \\
3,0\end{array}$ & 8,65 & $\begin{array}{l}6,200 \\
3,800\end{array}$ & $\begin{array}{l}2,263 \\
1,387\end{array}$ & $\begin{array}{c}19,575 \\
7,199\end{array}$ \\
\hline \multirow[t]{3}{*}{5.} & Breeding boars & & & & & \\
\hline & - basic & $\overline{c 1,0}$ & $\overline{c 1,73}$ & $\begin{array}{l}3,700 \\
\end{array}$ & 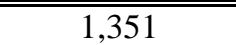 & 2,336 \\
\hline & Total & 100,0 & 173,00 & & & 138,438 \\
\hline
\end{tabular}

Table 6 - Calculation of the total consumption of feed for pigs in Ukraine in 2023

\begin{tabular}{|c|c|c|c|c|c|c|}
\hline № & $\begin{array}{l}\text { Pigs in the herd } \\
\text { structure }\end{array}$ & $\begin{array}{c}\text { Share in } \\
\text { the struc- } \\
\text { ture of the } \\
\text { herd, \% }\end{array}$ & $\begin{array}{l}\text { Number in the } \\
\text { structure of the } \\
\text { herd (5702 } \\
\text { thousand } \\
\text { heads, thou- } \\
\text { sand heads), } \\
\mathrm{K}_{\text {pig forecast }}\end{array}$ & $\begin{array}{c}\text { Average daily } \\
\text { consumption } \\
\text { of compound } \\
\text { feed per pig, } \\
\mathrm{kg}, \\
\mathrm{N}_{\text {mf pig day }}[5- \\
8] \\
\end{array}$ & $\begin{array}{c}\text { Average annu- } \\
\text { al consumption } \\
\text { of compound } \\
\text { feed per pig, } \\
\text { tons, } \\
\mathrm{N}_{\text {mf pig year }}\end{array}$ & $\begin{array}{c}\text { Total annual con- } \\
\text { sumption of } \\
\text { compound feeds } \\
\text { by pigs, thousand } \\
\text { tons, } \\
\mathrm{S}_{\text {mf pig forcast }}\end{array}$ \\
\hline \multirow[t]{7}{*}{1.} & Dairy stage & 20,0 & & & & \\
\hline & Suckling piglets & & & & & \\
\hline & - 0-2 weeks & 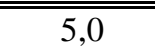 & 285,1 & 0,025 & 0,009 & 2,566 \\
\hline & - 2-4 weeks & $\overline{5,0}$ & 285,1 & 0,25 & 0,091 & 25,944 \\
\hline & Piglets at weaning & & & & & \\
\hline & - 1 month & $\overline{5,0}$ & 285,1 & 0,35 & 0,128 & 36,493 \\
\hline & -2 months & $\overline{5,0}$ & 285,1 & 0,85 & $0,0,310$ & 88,381 \\
\hline
\end{tabular}




\begin{tabular}{|c|c|c|c|c|c|c|}
\hline \multirow{4}{*}{ ב2. } & Staging stage & 25,0 & & & & \\
\hline & "Weaned piglets & & & & & \\
\hline & - 3 months & 12,5 & 7112,75 & $1,1,05$ & 0,383 & 272,983 \\
\hline & - 4 months & 12,5 & 712,75 & 1,55 & 0,566 & 403,417 \\
\hline \multirow[t]{6}{*}{3.} & The fattening stage & 446,0 & & & & \\
\hline & Young & & & & & \\
\hline & - 5 months & 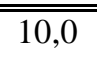 & 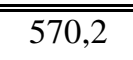 & 2,25 & "0,821 & 468,134 \\
\hline & -6 months & $\overline{111,0}$ & 627,22 & 2,55 & 0,931 & $\overline{583,942}$ \\
\hline & - 7 months & 12,0 & "684,24 & 3,2 & 1,168 & 7999,192 \\
\hline & - -8 months & 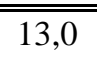 & "741,26 & 3,35 & $1,1,223$ & 906,561 \\
\hline \multirow[t]{3}{*}{4.} & Sows & & & & & \\
\hline & - basic & $\overline{5,0}$ & 285,1 & 6,2 & 2,263 & 645,181 \\
\hline & - checked & 3,0 & 171,06 & 3,8 & 1,387 & 237,260 \\
\hline \multirow[t]{2}{*}{$\bar{~} 5}$. & "Breeding boars & $\overline{12,0}$ & 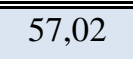 & 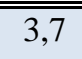 & 1,351 & "77,034 \\
\hline & Total & 100,0 & 5702,00 & & & 4547,088 \\
\hline
\end{tabular}

Table 7 - Data to calculate the required total capacity of feed mills in the Odessa region in 2023, thousand tons

\begin{tabular}{|c|c|}
\hline Indicator & Value \\
\hline Region & Odessa \\
\hline $\begin{array}{l}\text { Total annual consumption in } 2023 \\
S_{\text {mf forecast }}\end{array}$ & 104854,4 \\
\hline $\begin{array}{l}\text { Production volume in } 2022 \\
\mathrm{~V}_{\text {mf forecast }}\end{array}$ & 36,2 \\
\hline $\begin{array}{l}\text { Export to other regions and abroad, } \\
\text { E }_{\text {mf forecast }}\end{array}$ & 1,6 \\
\hline $\begin{array}{l}\text { Imports from other regions and from } \\
\text { abroad, I } \mathrm{m}_{\mathrm{mf}} \text { forecast }\end{array}$ & 0,2 \\
\hline Forecast production potential, $\mathrm{P}_{\text {mf forecast }}$ & 104819,6 \\
\hline
\end{tabular}

As a result we will receive:

$\mathrm{V}_{\text {mf pig forecast }}=8246 \cdot 1,434=34481.6$ tons

or 34.5 thousand tons,

$\mathrm{V}_{\mathrm{mf} \text { chickens forecast }}=1711 \cdot 1.04=1711$ tons or 1.7 thousand tons.

As a result, the projected volume of feed production for pigs and chickens in the Odessa region in 2023 will be equal to:

$\mathrm{V}_{\text {mf forecast }}=34.5+1.7=36.2$ thousand tons.

Exports (exports) and imports (imports) of grain crops from Odessa region to other regions and abroad in 2019 according to statistics - in Odessa region was 4.5 and $0.5 \%$ in the structure of feed production for farm animals, respectively. As a result, in the forecast period, it will be equal to:

$\mathrm{E}_{\mathrm{mf} \text { forecast }}=0.045 \times 36.2=1.6$ thousand tons.

$\mathrm{I}_{\mathrm{mf} \text { forecast }}=0.005 \times 36.2=0.2$ thousand tons.

Substitute in formula 9 the values of the obtained indicators. In our case, the projected potential for the production of feed for pigs and chickens in the
Odessa region in 2023 should cover the following consumption:

$\mathrm{P}_{\text {mf forecast }}=104854,4-36,2+1,6-0,2=$ $=104819,6$ thousand tons

We compare the forecast potential of feed production in the region $\left(\mathrm{P}_{\text {mf forecast }}\right)$ with the capacity of the feed company ( $\mathrm{M}_{\text {year }}$ ), for which we calculate the annual capacity of the company.

$\mathrm{M}_{\text {year }}=\mathrm{M}_{\text {changes }} \bullet \mathrm{H}_{\text {changes }} \bullet \mathrm{H}_{\text {days }}$, thousand tons, (13)

where $\mathrm{M}_{\text {year }}$ - the annual capacity of the enterprise, thousand tons;

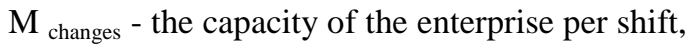
thousand tons;

$\mathrm{H}_{\text {changes }}$ - the number of shifts per day;

$\mathrm{H}_{\text {days }}$ - the number of working days per year of the feed business.

Then the annual capacity of the feed company is equal to:

$M_{\text {year }}=15$ thousand tons / shift $\bullet$

2 shifts $\cdot 300$ days $/$ year $=9,000$ thousand tons $/$

year

Based on the analysis of the $\mathrm{P}_{\mathrm{mf}}$ forecast and its comparison with $\mathrm{M}_{\text {year }}$, the following conclusions can be drawn:

- if $\mathrm{P}_{\mathrm{mf}}$ forecast $>0$, then in this region there is a deficit of production volumes;

- if $\mathrm{P}_{\mathrm{mf} \text { forecast }} \leq 0$, then in this region there is a surplus (surplus) of production;

- if $\mathrm{P}_{\mathrm{mf} \text { forcast }} \geq \mathrm{M}_{\text {year }}$, then the work of the feed mill of the planned capacity in this region is possible and appropriate;

- if $\mathrm{P}_{\mathrm{mf} \text { forcast }}<\mathrm{M}_{\text {year }}$, then the work of the feed company in this region is not appropriate.

Thus, the calculations showed that in the Odessa region there is a shortage of capacity, namely:

$\mathrm{P}_{\text {mf forecast }}=104819.6$ thousand tons. $>0$, 
P kk forecast $\geq M$ year ie $104819.6>9000.0$ thousand tons, therefore the compound feed enterprise in the Odessa area of the planned capacity of 15 thousand tons in change at two-shift work is expedient and reasonable.

The volume of production $\left(\mathrm{OV}_{\text {year }}\right)$ of the feed business is calculated by the formula:

$\mathrm{OV}_{\text {year }}=\mathrm{K}_{\mathrm{o}} \times \mathrm{M}_{\text {year }}$, thousand tons,

where $\mathrm{K}_{\mathrm{o}}-$ power utilization factor, share in $\%$; fluctuates within $\mathrm{Ko}=0.8 \ldots 0.9$.

Determine $\mathrm{Ko}=90 \%$ or $\mathrm{Ko}=0.9$ and base-mo in formula 18:

$\mathrm{OV}_{\text {year }}=0.9 \times 9000=8100$ thousand tons.

Then the volume of production of $1 \%$ of premixes $\left(\mathrm{OV} \mathrm{P}_{\mathrm{P} \text { yer }}\right)$ at the enterprise is calculated by the formula:

$$
\mathrm{OV}_{\mathrm{P} \text { year }}=\mathrm{OV}_{\text {year }} \times 0,01, \text { thousand tons, }(15)
$$

$\mathrm{OV}_{\text {P year }}=8100 \times 0.01=81$ thousand tons.

Then the production volume of $30 \%$ of BVS $(\mathrm{OV}$ Bvs year) at the enterprise is calculated by the formula:

$\mathrm{OV}_{\text {BVS year }}=\mathrm{OV}_{\text {year }} \times 0,3$, thousand tons, (16)

$\mathrm{OV}_{\text {BVS year }}=8100 \times 0.3=2430$ thousand tons.

\section{Conclusions}

1. Thus, we analyzed the main trends in the market of pork, chicken and feed for farm animals of Ukraine, conducted a study of these markets in the Odessa region, based on which the need to produce up to 8500 thousand tons of feed, 85 thousand tons of premixes and 2430 thousand tons of BVS for Odessa region.

2. Estimation of economic efficiency of introduction of the developed receptions of premixes, BVS and the improved technology of their production

The production of chicken eggs in Ukraine fully meets the needs of Ukrainian consumers, in particular in 2017 the production of chicken eggs is about 14 billion pieces. According to the data of 2017, the volume of pork production is 1576 thousand tons.

According to zootechnical studies on laying hens, it was found that the introduction of developed energy-saving technology for the production of highquality premixes in the production of feed can reduce the cost of feed to $46 \mathrm{UAH}$, the cost of obtaining 1 dozen chicken eggs - from 0.2 UAH. up to UAH 0.5

Economic efficiency from the use of compound feeds enriched with complex premixes is determined by the formula, UAH

$$
E_{\text {s }}=\frac{O \times B}{10},
$$

where $\mathrm{O}$ - is the volume of egg production per year, billion pieces, $\mathrm{O}=14$ billion pieces; $0.2 \mathrm{UAH}$

$\mathrm{B}$ - reduction of costs for obtaining 10 eggs, $\mathrm{B}=$ 10 - a dozen eggs.

$$
E_{s}=\frac{14000 \times 10^{6} \times 0,2}{10}=280 \times 10^{6}
$$

The introduction of the developed energy-saving technology, the production of complex premixes allows to reduce the cost of obtaining 10 eggs to 280 million $\mathrm{UAH}$. in a year.

According to data for 2018 in Ukraine, the average citizen consumes $12.6 \mathrm{~kg}$ of pork per year [1, 9, 11]. According to the Ministry of Health of Ukraine, the rate of meat consumption per year should be about $30 \mathrm{~kg}$ to ensure protein nutrition. Given that in the mid-1980s one person in Ukraine consumed $53 \mathrm{~kg}$ of pork, it can be assumed that the potential monetary capacity of the pork market could be increased 2.4 times.

According to the data of feeding suckling piglets compound feeds with the use of complex premixes, the cost of pork meat has been reduced by UAH $2 \ldots 3$.

The economic efficiency of feeding suckling piglets with compound feeds enriched with complex premixes is:

$$
\mathrm{Em}=2 \times 1576 \times 10^{6}=3152 \times 10^{6} \mathrm{UAH} .
$$

Thus, it is possible to save up to UAH 3.15 million in the production of pork.

\section{REFERENCES}

1. Statystychnyy shchorichnyk Ukrayiny. 2018 rik. Derzhavna sluzhba statystyky Ukrayiny. URL: http://www.ukrstat.gov.ua

2. Poholiv"ya svyney v Ukrayini. Poholiv"ya sviys'koyi ptytsi v Ukrayini. Holovnyy m"yasnyy infoportal Ukrayiny. URL : https://meatinform.com

3. Tendentsiyi poholiv"ya khudoby ta ptytsi $v$ Ukrayini. Ukrayins'kyy klub ahrarnoho biznesu. URL http://ucab.ua/ua/pres_sluzhba/novosti/tendentsii_chiselnosti_pogolivya_khudobi_ta_ptitsi_v_ukraini

4. Metodychni vkazivky do vykonannya rozdiliv «Tekhniko-ekonomichne obhruntuvannya», "Tekhniko-ekonomichni pokaznyky» dyplomnoho proektu na temu: «Budivnytstvo novoho kombikormovoho pidpryyemstva» dlya studentiv osvitn'oho rivnya «bakalavr» $i$ «mahistr» spetsial'nosti 181 «Kharchovi tekhnolohiyi» haluzi znan' «Vyrobnytstvo ta tekhnolohiyi» osvitn'oyi prohramy "Kormova bioinzheneriya» dennoyi ta zaochnoyi form navchannyal za red. d.e.n., dots. Basyurkinoyi N.Y. Odesa: ONAKHT, 2020. 25.

5. Tekhnolohiya vyrobnytstva produktsiyi tvarynnytstva : pidruchnyk/za red. O.T. Busenka. Kyyiv: Vyshcha osvita, 2005.496.

6. Tekhnolohiya vyrobnytstva produktsiyi svynarstva : pidruchnyk / [V.I. Herasymov ta in.], za red. V.I. Herasymova. Kharkiv: Espada, 2010. 448 .

7. Osnovy normovanoyi hodivli svyney (vyrobnycho-praktychni rekomendatsiyi) / Topikha V.S. ta in]. Mykolayiv : MNAU, 2016.51.

8. Skil'ky kormu potribno svyni dlya vidhodivli. URL : https://feedlife.com.ua/ua/info/skolko-korma-nuzhno-svine/?_err=1587680587

9. Poultru Market. Ptakhivnytstvo Ukrayiny ta svitu. URL : http://market.avianua.com/?p=4350\#more -4350

10. Patryeva L.S., Koval' O.A. Tekhnolohiya vyrobnytstva produktsiyi ptakhivnytstva: kurs lektsiy. Mykolayiv : MNAU, 2018.248.

11. Vyrobnytstvo promyslovoyi produktsiyi za vydamy u 2019 rotsi. Holovne upravlinnya statystyky $v$ Odes'kiy oblasti. URL . http://www.od.ukrstat.gov.ua 
Н.Й. Басюркіна, д-р екон. наук, професор, E-mail:nbas@ gmail.com

Б.В. Сгоров, д-р техн. наук, професор, E-mail: bogdanegoroff58@ gmail.com

А.В. Макаринська, канд. техн. наук, доцент, E-mail: allavm2015@ gmail.com Одеська національна академія харчових технологій, вул. Канатная, 112, м. Одеса, 65039, Украӥна

\title{
ОЦІНКА ПОТРЕБ ТА ЕКОНОМІЧНОЇ ЕФЕКТИВНОСТІ ПРЕМІКСІВ, БІЛКОВО-ВІТАМІННИХ ДОБАВОК І КОМБІКОРМІВ
}

\begin{abstract}
Анотація
В матеріалах статті наведено статистичні дані кількості свиней і птиці свійської в Украйні та Одеській області за 1990-2019 роки та результати розрахуноку потреб у преміксах і білково-вітамінних добавок (БВД) в Україні, та зокрема, в Одеській області, середній приріст та обсяги споживання комбікормів. Основною метою розрахунку є визначення потенціалу виробництва преміксів і комбікормів в Украӥні та у регіоні, витрат комбікормів при вирощуванні сільськогосподарської птиці з застосуванням різних видів преміксів та БВД.

За даними Головного управління статистики в Одеській області встановлено, що за останні п'ять років відбулося зменшення кількості поголів'я свиней, а кількість птиці зросла на 7,3\%.

Розрахунок потреб у преміксах і БВД визначається обсягами виробництва комбікормів, потреба в яких залежить від чисельності поголів'я сільськогосподарських тварин і птиці, даних про їх середній приріст та обсяги споживання комбікормів.

Наведено методику розрахунку чисельності поголів'я свиней і свійської птиці (прогноз) в залежності від потреб населення у тваринницьких харчових продуктах, а також представлені результати прогнозу кількості свиней $і$ свійських курей в Украйні та в Одеській області на 2020-2023 роки, які склали 5702,0 та 173,0 тис. голів, 224,8 та 3,3 млн. голів, відповідно.

Проведені розрахунки з врахуванням експортно-імпортного потенціалу сировини показали, щяо в Одеській облас-

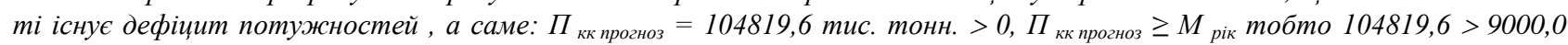
тис. тонн, тому в Одеській області слід передбачити комбікормове підприємство потужністю 15 тис. тонн у зміну при двозмінній роботі є доцільним та обтрунтованим. Розраховано потенціал виробництва і реалізація комбікормів в Одеському регіоні, який становить до 8500 тис. тонн комбікормів, 85 тис.т преміксів та 2430 тис. тонн БВД, досліджено основні виробники і споживачі комбікормової продукиії.

Очінена економічна ефективність від використання комбікормів, збагачених комплексними преміксами, в результаті чого можна зменшити витрати на отримання 10 яєць до 280 млн. грн. за рік, а при відгодівлі поросят-сосунів - зекономити при виробництві м'яса свинини до 3,15 млн. грн.
\end{abstract}

Ключові слова: комбікорми для індиків, фізичні властивості, хімічний склад, білкова кормова добавка, соєвий шрот, показники поживної иінності.

\section{ЛІТЕРАТУРА}

1. Статистичний щорічник України. 2018 рік. Держсавна служба статистики України. URL: http://www.ukrstat.gov.ua/

2. Поголів'я свиней в Украӥні. Поголів'я свійської птиці в Украӥні. Головний м'ясний інфопортал Украӥни. URL : https://meatinform.com

3. Тенденції поголів'я худоби та птиці в Украӥні. Украӥнський клуб аграрного бізнесу. URL: http://ucab.ua/ua/pres_sluzhba/novosti/tendentsii_chiselnosti_pogolivya_khudobi_ta_ptitsi_v_ukraini

4. Методичні вказівки до виконання розділів «Техніко-економічне обгрунтування», «Техніко-економічні показники» дипломного проекту на тему: «Будівництво нового комбікормового підприємства» для студентів освітнього рівня «бакалавр» $i$ «магістр» спеціальності 181 «Харчові технології» галузі знань «Виробництво та технології» освітньої програми «Кормова біоінженерія» денної та заочної форм навчання/ за ред. д.е.н., дои. Басюркіної Н.Й. - Одеса: ОНАХТ, 2020. - 25 с.

5. Технологія виробництва продукиї̈ тваринництва : підручник / за ред. О.Т. Бусенка. Київ: Вища освіта, 2005. 496 с.

6. Технологія виробництва продукиї̈ свинарства : підручник / [B.I. Герасимов та ін.], за ред. В.І. Герасимова. Харків: Еспада, 2010. 448 c.

7. Основи нормованої годівлі свиней (виробничо-практичні рекомендації) / Топіха В.С. та ін]. Миколаїв : МНАУ, 2016 , 51 с.

8. Скільки корму потрібно свині для відгодівлі. URL: https://feedlife.com.ua/ua/info/skolko-korma-nuzhnosvine/?_err $=1587680587$

9. Poultry Market. Птахівництво України та світу. URL: http://market.avianua.com/?p=4350\#тоre-4350

10. Патрєва Л.С., Коваль О.А. Технологія виробництвва продукиії птахівнищтва: курс лекиій. Миколаїв : МНАУ, 2018. 248 с.

11. Виробництво промислової продукцї̈ за видами у 2019 рочі. Головне управління статистики в Одеській області. URL: http://www.od.ukrstat.gov.ua

\section{Received 22.06.2020 \\ Reviewed 07.07.2020}

Revised $\quad 30.10 .2020$

Approved 01.12.2020

Cite as Vancouver Citation Style

Basiurkina N., Yegorov B., Makarynska A. Assessment of the needs and economic efficiency of premixes, protein and vitamin supplements and compound feeds in Ukraine // Grain Products and Mixed Fodder's, 2020. 20.4 (80).: 38-46. DOI https://doi.org/

Cite as State Standard of Ukraine 8302:2015

Assessment of the needs and economic efficiency of premixes, protein and vitamin supplements and compound feeds in Ukraine / Basiurkina N. et al. // Grain Products and Mixed Fodder's, 2020. Vol. 20. I. 4 (80). P. 38-46. DOI https://doi.org/ 